\title{
PENGGUNAAN E-LEARNING DALAM PEMBELAJARAN BAHASA INDONESIA DI SMA NEGERI BALI MANDARA
}

\author{
I Putu Darmika ${ }^{1}$, Gede Gunatama², I Made Sutama $^{3}$ \\ Jurusan Pendidikan Bahasa dan Sastra Indonesia, Fakultas Bahasa dan Seni \\ Universitas Pendidikan Ganesha \\ Singaraja \\ e-mail: Darmikaigede@gmail.com ${ }^{1}$,gedegunatama22@gmail.com², \\ imadesutamaubd@gmail.com ${ }^{3}$
}

\begin{abstract}
ABSTRAK
Penelitian ini bertujuan untuk mendeskripsikan (1) isi dan daya dukung e-learning dalam pembelajaran bahasa Indonesia di SMA Negeri Bali Mandara, (2) penerapan e-learning dalam pembelajaran bahasa Indonesia di SMA Negeri Bali Mandara, dan (3) respons peserta didik terhadap penggunaan e-learning dalam pembelajaran bahasa Indonesia. Penelitian ini menggunakan rancangan penelitian deskriptif kualitatif-kuantitatif. Subjek penelitian ini adalah guru mata pelajaran bahasa Indonesia dan peserta didik kelas XI IPA I dan IPA II SMA Negeri Bali Mandara. Objek penelitian ini adalah penggunaan e-learning dalam pembelajaran bahasa Indonesia. Data dalam penelitian ini dikumpulkan melalui metode observasi, wawancara, dokumentasi, dan kuesioner (angket).Temuan dalam penelitian ini adalah (1) isi e-learning dalam pembelajaran bahasa Indonesia,ada lima yaitu: (a) kode kelas, (b) materi bahasa Indonesia,(c) materi tambahan (d) tugas online, dan (e) hasil asessment. Sementara daya dukung e-learning dalam pembelajaran bahasa Indonesia di SMA Negeri Bali Mandara ada tiga, yaitu: (a) mempermudah guru dalam mengajar, (b) mendukung materi dalam silabus, (c) memfasilitasi evaluasi online. (2) Penerapan e-learning dalam pembelajaran bahasa Indonesia di SMA Negeri Bali Mandara, yaitu dalam bentuk blended learning (3) Respons peserta didik terhadap penggunaan e-learning dalam pembelajaran bahasa Indonesia, yaitu sangat positif $(31,45 \%)$ dengan rincian terdapat 21 (47,72\%) memberikan resposn sangat setuju dan $23(52,27 \%)$ memberikan respons setuju.
\end{abstract}

Kata kunci : Penggunaan e-learning, isi, dan daya dukung e-learning, dan respons peserta didik.

\section{ABSTRACT}

This research intended to describe (1) the content and supportability of e-learning in Indonesian language learning in SMA Negeri Bali Mandara, (2) the application of elearning in Indonesian language learning in SMA Negeri Bali Mandara, and (3) the response of thestudents due to the application of e-learning in Indonesian language learning. This research used descriptive qualitative-quantitative as the research design. The subjects of this study were Indonesian language teachers and the students of class XI IPA I and IPA II of SMA Negeri Bali Mandara. The object of this research was the application of e-learning in Indonesian language learning. The data in this research were collected through observation method, interview, documentation, and questionnaire. The findings of this research were (1) the content of e-learning in Indonesian language learning there are five, those were: (a) class code, (b) Indonesian language material, (c) additional material (d) online task, and (e) assessment results. Meanwhilethe supportability of e-learning in Indonesian language learningin SMA Negeri Bali Mandara there are three, those were: (a) facilitate the teachers in teaching, (b) support the material in the syllabus, (c) 
facilitate the online evaluation. (2) The application of e-learning in Indonesian language learning in SMA Negeri Bali Mandara, those were in the form of blended learning, (3) The response of students due to the application of e-learning in Indonesian language learning, that was very positive $(31.45 \%)$ with details there were $21(47,72 \%)$ gave response strongly agree and $23(52,27 \%)$ gave response agree .

Keywords : Application of e-learning, content and supportability of e-learning, and student's response.

\section{PENDAHULUAN}

Belajar merupakan suatu proses dalam penyelenggaraan pendidikan. Belajar sebagai kunci dari berhasilnya sebuah tujuan dalam dunia pendidikan yang ditandai dengan perubahan perilaku peserta didik yang relatif positif sebagai wujud adanya interaksi dengan lingkungan. Pembelajaran menurut Suherman (dalam, Jihad dan Haris, 2013:11) merupakan proses komunikasi antara peserta didik dan pendidik dalam rangka perubahan sikap. Pengertian pembelajaran atau learning adalah suatu proses yang dilakukan peserta didik untuk mencapai sasaran belajarnya. Agar peserta didik dapat mencapai sasaran belajar secara optimal, maka peserta didik perlu menambah waktu belajar di luar kelas untuk membaca, menulis, diskusi dengan peserta didik lain, menyelesaikan soal-soal, dan lain-lain. Berikutnya, skenario pembelajaran formal di kelas menjadi belajar bersifat informal, terjadi di tempat-tempat yang tak terduga dan pada waktu yang tidak terduga.

Proses belajar mengajar hakikatnya adalah proses penyampaian pesan dari pengantar ke penerima. Daryanto (2013:5) menyatakan pesan dalam pembelajaran berupa isi ajaran yang dituangkan ke dalam simbol-simbol komunikasi, baik verbal ( kata-kata dan tulisan) maupun nonverbal, proses ini dinamakan encoding. Dengan demikian, pembelajaran yang merupakan suatu komunikasi, maka untuk mempermudah dalam menyampaikan pesan diperlukan media pembelajaran. Menurut Daryanto (2013:5) media pembelajaran merupakan media yang digunakan sebagai alat dan bahan kegiatan pembelajaran. Daryanto (2013:7) menyatakan, tanpa media, komunikasi tidak akan terjadi dan proses pembelajaran sebagai komunikasi juga tidak akan bisa berlangsung secara optimal.

$$
\text { Menurut Prakoso }
$$

teknologi internet mengemuka sebagai media yang multirupa. Komunikasi melalui internet bisa dilakukan secara interpersonal (misalnya email dan chattting) atau secara massal, yang dikenal one to many communication (misalnya mailing list). Internet juga mampu hadir secara real time audio visual seperti pada metode konvensual dengan adanya aplikasi teleconference. Berdasarkan hal tersebut perkembangan teknologi telah membawa manusia pada ruang yang mampu memberikan kemudahan dalam kesehariannya. Hal yang paling sederhana adalah mempermudah komunikasi baik secara individu maupun secara berkelompok. Kemudahan tersebut diharapkan merambat pada bidang pendidikan. Pendidikan sebagai hal penting bagi manusia diharapkan dapat dipermudah melalui teknologi.

Pendidikan pada umumnya semakin berkembang dengan adanya teknologi. Teknologi akan memberikan keleluasaan kepada guru dalam memberikan materi kepada peserta didik. Dengan memanfaatkan teknologi guru akan mampu menerapkan strategi pembelajaran yang lebih baik, sehingga guru menjadi lebih kreatif, inovatif, dan berkualitas. Untuk menjawab tantangan pada dunia pendidikan tersebut diperlukan teknologi yang dapat menyediakan pendidikan dengan metode yang lebih efektif, cepat dan persiapannya lebih singkat.Salah satu implementasi teknologi tersebut adalah $E$ learning. E-learning merupakan terobosan baru dalam dunia pendidikan.

"E-learning" tersusun dari dua bagian, yaitu 'e' yang merupakan singkatan 
dari 'elektronik' dan 'learning' yang berarti 'pembelajaran'. Gilbertdan Jones (2001) serta Michael (2013) (dalam Wahyuningsing dan Makmur, 2017:3) mengemukakan bahwa "e-learning merupakan segala bentuk aktivitas pembelajaran yang memanfaatkan media elektronik untuk belajar. Sejalan dengan itu, Effendi dan Zhuang mengungkapkan kata e-learning sering digunakan untuk semua kegiatan pendidikan yang menggunakan media komputer atau internet. Daryanto (2013:168) menyatakan bahwa e-learning merupakan sistem pembelajaran yang memanfaatkan media elektronik sebagai alat untuk membantu kegiatan pembelajaran. Berdasarkan pandangan tersebut dapat disimpulkan e-learning merupakan pembelajaran dengan menggunakan jasa bantuan perangkat elektronika seperti komputer maupun internet .

Dalam pelaksanaannya, e-learning menggunakan jasa audio, video atau perangkat komputer atau kombinasi dari ketiganya. E-learning merupakan suatu kemajuan penting dalam sistem pendidikan modern. Oleh karena itu, metode, dan isi $e-$ learning membuat perubahan dan tantangan baru dalam dunia pendidikan.Penggunaan e-learning pada pembelajaran telah terbukti memberikan keuntungan dalam pembelajaran. Effendi dan Zhuang (2005:9) memaparkan beberapa kelebihan yang ditawarkan $e$ learning yaitu: (1) dari segi biaya, (2) yang kedua fleksibilitas waktu, (3) fleksibilitas tempat, (4) fleksibilitas kecepatan pembelajaran, (5) standarisasi pengajaran, (6) efektivitas pengajaran, (7) kecepatan distribusi, (8) ketersediaan on-demand, dan (9) otomatis proses administrasi.

Peneliti memilih SMA Negeri Bali Mandara karena beberapa alasan yaitu: (1) SMA Negeri Bali Mandara menggunakan Kurikulum 2013 dengan pembelajaran yang menggunakan Sistem Kredit Semester (SKS), (2) SMA Negeri Bali Mandara dalam proses pembelajarannya telah terbukti memanfaatkan e-learning dengan baik, dan konsisten. (3) SMA Negeri Bali Mandara sudah menerapkan kebijakan-kebijakan baru dari pemerintah. (4) SMA Negeri Bali Mandara adalah sekolah yang menerapkan full day school. (5) guru-guru di SMA Bali Mandara menggunakan strategi pembelajaran mandiri dengan menggunakan UKBM. Salah satunya adalah pada pembelajaran bahasa Indonesia, (6) meskipun baru berdiri beberapa tahun yang lalu, SMA Negeri Bali Mandara sudah banyak meraih prestasi dari kancah antar sekolah, kecamatan, kabupaten, provinsi, nasional, hingga internasional, baik dibidang akademik maupun nonakademik serta menghasilkan lulusan yang berkualitas

Penelitian penggunaan e-learning dalam pembelajaran bahasa Indonesia khususnya belum pernah dilakukan. Namun, beberapa penelitian sejenis juga telah dilakukan tentunya memiliki perbedaan dengan penelitian yang peneliti rancang. Adapun penelitian sejenis tersebut adalah sebagai berikut. Penelitian pertama Gusti Ngurah Yogi Maha Putra pada tahun 2016 dari Universitas Pendidikan Ganesha dengan judul "Pengaruh Penggunaan ELearning Berbasis Edmodo Terhadap Prestasi Belajar Matematika Peserta Didik Kelas X Paket Keahlian Teknik Gambar Bangunan SMK Negeri 3 Singaraja". Penelitian kedua oleh I Gusti Ngurah Yatra Pratistha pada tahun 2016 dari Universitas Pendidikan Ganesha dengan judul "Efektivitas Media Pembelajaran E-learning Berbasis Quipper School Terhadap Pemahaman Konsep Matematika Peserta didik kelas $X$ di SMA Laboratorium Undiksha". Penelitian ketiga oleh Siti Shofiah pada tahun 2016 dari Universitas Islam Negeri Maulana Malik Ibrahim Malang dengan judul " Pengaruh Penggunaan Android dan E-learning terhadap Hasil Belajar Mata Pelajaran IPS Peserta didik kelas VIII SMPN 3 Kepanjen Malang". Penelitian keempat oleh Kadek Ferry Apriana pada tahun 2015 dari Universitas Pendidikan Ganesha dengan judul " Pengembangan Portal E-learning Berbasis Schoology Pada Mata pelajaran IPS Kelas VIII di SMPN 1 Banjarangkan".

Keempat penelitian tersebut memiliki persamaan dengan penelitian ini, yaitu 
sama-sama meneliti E-learning. Namun, keempat penelitian tersebut tentu saja memiliki perbedaan dengan penelitian ini, terutama pada subjek penelitian, dan lokasi penelitian.

Beranjak dari penelitian sejenis tersebut, peneliti ingin mengetahui dan mendeskripsikan Penggunaan E-learning dalam Pembelajaran Bahasa Indonesia di SMA Negeri Bali Mandara. Penelitian ini juga akan melihat isi dan daya dukung $e$ learning dalam pembelajaran bahasa Indonesia di SMA Negeri Bali Mandara, penggunaan e-learning dalam pembelajaran bahasa Indonesia di SMA Negeri Bali Mandara,dan respons peserta didik terhadap penggunaan e-learning dalam pembelajaran bahasa Indonesia di SMA Negeri Bali Mandara.

Tujuan penelitian ini adalah (1) Mendeskripsikan isi dan daya dukung $e$ learning dalam pembelajaran bahasa Indonesia di SMA Negeri Bali Mandara (2) Mendeskripsikan penerapan e-learning dalam pembelajaran bahasa Indonesia di SMA Negeri Bali Mandara, dan (3) Mendeskripsikan respons peserta didik terhadap penggunaan e-learning dalam pembelajaran bahasa Indonesia di SMA Negeri Bali Mandara.

Manfaat penelitian ini adalah (1) Hasil penelitian ini dapat menyumbangkan teori penggunaan e-learning dalam pembelajaran sebagai sumber belajar, khususnya pada pembelajaran bahasa Indonesia, (2) Penelitian ini dapat memberikan manfaat untuk peserta didik untuk meningkatkan prestasi belajar, (3) bagi guru penelitian ini dapat dijadikan pedoman untuk meningkatkan pembelajaran di kelas, dan (4) bagi sekolah penelitian ini dapat dimanfaatkan untuk pertimbangan untuk merancang pembelajaran yang lebih baik.

\section{METODE PENELITIAN}

Penelitian ini menggunakan rancangan deskriptif kualitatif-kuantitatif. Penelitian ini diharapkan mampu menggambarkan penggunaan e-learning dalam pembelajaran bahasa Indonesia di SMA Negeri Bali Mandara. Subjek dalam penelitian ini adalah guru mata pelajaran bahasa Indonesia dan peserta didik kelas XI IPA, dan XI IPA II. Sedangkan objek penelitian ini adalah penggunaan e-learning dalam pembelajaran bahasa Indonesia. Metode pengumpulan data dalam penelitian ini meliputi metode observasi, wawancara, dokumentasi, dan kuesioner (angket). Pada penelitian ini metode observasi yang digunakan adalah metode observasi nonpartisipatif karena peneliti hanya ingin melihat situasi dari proses penggunaan $e$ learning dalam pembelajaran bahasa Indonesia di SMA Negeri Bali Mandara yang dilakukan secara alami oleh peserta didik. Instrumen yang digunakan dalam observasi adalah lembar observasi yang berfungsi untuk mencatat hasil observasi. Data yang sudah dicatat akan dianalisis untuk mengetahui penerapan e-learning dalam pembelajaran bahasa Indonesia di SMA Negeri Bali Mandara.

Metode wawancara juga digunakan dalam penelitian ini. Metode wawancara dalam penelitian digunakan untuk mendapatkan data mengenai manfaat $e$ learning bagi guru dan peserta didik dalam pembelajaran bahasa Indonesia. Pada penelitian ini juga digunakan metode dokumentasi. Metode dokumentasi digunakan untuk mendapatkan data mengenai isi dan daya dukung e-learning dalam pembelajaran bahasa Indonesia.Selanjutnya pada penelitian ini juga digunakan metode angket. Metode kuesioner (angket) digunakan untuk mendapatkan data mengenai respons peserta didik terhadap penerapan elearning dalam pembelajaran bahasa Indonesia.

Pada penelitian ini metode analisis data yang digunakan adalah metode deskriptif kualitatif-kuantitatif. Prosedur pengolahan data dalam penelitian ini yaitu model analisis Miles dan Huberman (dalam Sugiono, 2007 :338) yang meliputi (a) reduksi data, (b) penyajian data, dan (c) penarikan simpulan. Data tentang isi dan daya dukung e-learning, penggunaan $e$ learning, dan manfaat penggunaan $e$ - 
learning bagi guru dan peserta didik dalam pembelajaran bahasa Indonesia di SMA Negeri Bali Mandara akan dianalisis dengan teknik deskriptif kualitatif. Sedangkan, data mengenai respons peserta didik terhadap penggunaan $e$ learning dalam pembelajaran bahasa Indonesia di SMA Negeri Bali Mandara dianalisis menggunakan teknik deskriptif kuantitatif.

\section{HASIL DAN PEMBAHASAN}

Setelah dilakukan analisis data mengenai penggunaan e-learning dalam pembelajaran bahasalndonesia di SMA negeri Bali Mandara diperoleh hasil seperti berikut ini.

Berdasarkan data yang didapatkan mengenai isi dan daya dukung e-learning dalam pembelajaran bahasa Indonesia di SMA Negeri Bali Mandaramenggunakan quipper, dan schoology.

Isi pada quipper berupa konten yang telah memiliki fungsinya masing-masing dengan tujuan masuk ke materi pelajaran yang tersedia dalam kelas maya, yang sudah disesuaikan dengan silabus. Konten tersebut meliputi (1) Kode kelas. Kode kelas berguna untuk memungkinkan peserta didik masuk ke kelas maya. Dengan masuk ke kelas maya dalam hal ini adalah penggunaan Quipper peserta didik dapat menggunakan e-learning dalam pembelajaran bahasa Indonesia, (2) Materi yang tersedia pada kelas maya. Materi yang tersedia adalah materi yang disesuaikan dengan silabus. Materi yang tersedia yang digunakan guru adalah materi yang sudah disesuaikan dengan silabus yang sudah ditetapkan, (3) tugas yang sedang aktif. Pada isi e-learning dalam penggunaan Quipper telah tersedia tugas online yang dapat dikerjakan peserta didik. Peserta didik akan masuk ke tugas online dan mendapatkan kesempatan untuk mengerjakan tugas sesuai dengan waktu yang sudah ditentukan, dan (4) hasil asessment. Pada konten hasil asesssment, assessment akan mucul setelah peserta didik mengerjakan semua tugas yang terdapat dalam kelas maya. Hasil ini nantinya akan digunakan sebagai pedoman apakah peserta didik sudah menguasai materi yang disediakan dalam kelas maya atau belum.

Isi pada schoology meliputi

Tampilan depan merupakan awal dalam penggunaan kelas maya Schology. Pada tampilan ini akan diberikan petunjuk untuk masuk ke langkah selanjutnya yaitu memasukan kode peserta didik, (2) Akses ke kelas maya dengan memasukkan kode agar dapat menggunakan kelas maya, (3) Materi yang tersedia adalah materi bahasa Indonesia. Dengan hal tersebut peserta didik dapat memanfaatkan materi tersebut sebagai bahan informasi untuk memperdalam pemahaman terhadap materi yang sudah disediakan, (4) materi tambahan. Selain itu apabila peserta didik belum paham peserta didik dapat mencari materi tambahan untuk mendapatkan pengetahuan. Materi tersebut dapat berupa video, salindia yang sudah disediakan, maupun artikel. Untuk mempermudah peserta didik memahami materi, guru dapat menampilkan film, dokumen penting sesuai materi, ataupun peserta didik dapat keluar mencari link (youtube) untuk mendapatkan materi tambahan agar lebih cepat memahami materi.

SMA Negeri Bali Mandara menggunakan e-learning dengan baik, sehingga isi sistem dapat mendukung pembelajaran bahasa Indonesia di SMA Negeri Bali Mandara. Daya dukung $e-$ learning dalam pembelajaran bahasa Indonesia di SMA Negeri Bali Mandara meliputi e-learning dapat mempermudah guru dalam mengajar. Penggunaan $e$ learning yang baik tentu akan mendukung pembelajaran. Pembelajaran bahasa Indonesia di SMA Negeri Bali Mandara telah berjalan dengan baik sehingga dengan keberadaan e-learning memiliki kontribusi yang tinggi bagi guru. Adanya konten-konten yang sudah memiliki fungsi tertentu dapat membantu guru dalam mengajar. Guru dapat memanfaatkan salindia untuk mempermudah dalam penyampaian materi, selain itu guru juga disediakan konten tugas aktif yang setiap saat dapat digunakan guru dalam menguji 
pemahaman peserta didik terkait pembalajaran bahasa Indonesia.

E-learning juga mendukung materi dalam silabus.Materi yang banyak terkadang tidak bisa dijelaskan secara maksimal pada kelas tatap muka. Hal tersebut berakibat pada kurangnya pemahaman peserta didik terhadap materi yang diajarkan. Pada pembelajaran bahasa Indonesia yang cenderung berbasis teks akan terlaksana dengan baik ketika didukung oleh penggunaan e-learning. $E$ learning memiliki daya dukung yang tinggi terhadap pembelajaran bahasa Indonesia. E-learning telah menyediakan materi yang disesuaikan dengan silabus. Disamping itu, memfasilitasi evaluasi online. Pada pembelajaran bahasa Indonesia evaluasi akan sangat diperlukan. Guru bahasa Indonesia di SMA Negeri Bali Mandara dengan e-learning dapat memberikan tugas kepada peserta didik setelah selesai pembelajaran. Tugas yang diberikan akan tersedia pada tugas aktif, peserta didik akan mengerjakan tugas tersebut ketika mereka membuka tugas aktif. Dengan demikian konten ini juga akan langsung menunjukan hasil dari tugas mereka, sehingga guru dapat bertindak lebih jauh mengenai hasil tugas mereka. Penilaian secara online yang dilakukan guru akan lebih mudah mengetahui pemahaman peserta didik, peserta didik yang benarbenar paham pasti akan berhasil begitu juga sebaliknya. Tingginya daya dukung $e-$ learning terhadap pembelajaran bahasa Indonesia juga tidak terlepas dari kemampuan sistem yang menyediakan kunci jawaban apabila peserta didik salah dalam menjawab

Hasil yang diperoleh terkait dengan penerapan e-learning dalam pembelajaran bahasa Indonesia di SMA negeri Bali Mandara, yaitu penerapan e-learning dalam pembelajaran bahasa Indonesia di SMA Negeri Bali Mandara yaitu, dalam bentuk blended learning. Penerapan blended learning dapat dikelompokkan menjadi tiga tahap yaitu, tahap pendahuluan, kegiatan inti, dan penutup. Berikut akan dijelaskan tahap-tahap blended learning yang dilakukan guru.
Kegiatan Pendahuluan meliputi Sehari sebelum pembelajaran di kelas, guru mengarahkan peserta didik untuk masuk ke kelas maya dengan memberikan kode kepada peserta didik agar bisa masuk ke kelas maya, Peserta didik masuk ke kelas maya dengan kode yang telah diberikan guru. Masuk ke dalam kelas maya sesuai dengan kode yang telah diberikan guru membuat peserta didik dapat ,menggunakan kelas maya. Dengan demikian, peserta didik bisa menggunakan kelas maya sesuai dengan arahan guru, Peserta didik mempelajari materi yang tersedia di kelas maya di asrama. Setelah peserta didik masuk ke kelas maya peserta didik dapat mengakses materi yang sudah ada pada kelas maya. Materi tersebut sudah disesuaikan dengan silabus jadi peserta didik tetap belajar sesuai dengan tahapan pada silabus. Peserta didik dapat mempelajari materi di asrama sebelum materi itu dibahas kembali di kelas tatap muka.

Kegiatan inti yang dimaksudkan adalah pembelajaran tatap muka. Berdasarkan pencatatan hasil observasi yang dilakukan peneliti, kegiatan inti pada blended learning, yaitu sebagai berikut. Pada kegiatan inti, guru mereview pemahaman peserta didik terhadap materi. Penggunaan blended learning dengan tujuan agar hasil pembelajaran lebih maksimal, peserta didik yang sudah mempelajari materi pelajaran bahasa Indonesia dengan e-learning atau di kelas maya tentu sudah memiliki pengetahuan dan pada pertemuan tatap muka pembahasan materi dilakukan guru dengan memberikan pertanyaan.

Pembahasan materi yang dilakukan secara tatap muka. Pembahasan materi pada tatap muka lebih terfokus pada materi yang belum dipahami peserta didik ketika belajar dengan di kelas maya, sehingga guru akan lebih mudah menjelaskan materi tersebut karena peserta didik telah memiliki gambaran akan materi yang diajarkan. Penugasan terhadap peserta didik, penugasan ini dilakukan secara online, artinya peserta didik kembali masuk ke kelas maya untuk menyelesaikan tugas 
yang disediakan ,maupun mencari informasi untuk menjawab tugas.

Penutup pelaksanaan blended learning. Pada bagian penutup dilakukan dengan menyimpulkan hasil pembelajaran secara bersama-sama. Penyimpulan ini cerminan dari tujuan pembelajaran yakni peserta didik mampu memahami materi yang diajarkan dan dapat mengimplikasikan pada kegiatan sehari-hari.

Hasil angket setelah disebar kepada peserta didik kelas XI IPA I dan XI IPA II menunjukkan bahwa terdapat empat jenis tanggapan peserta didik terhadap peryataan dalam angket yang diberikan yaitu sangat setuju, setuju, dan tidak setuju. Dari 44 peserta didik yang mengisi angket, ada 28 peserta didik (63,63\%) yang memberikan tanggapan sangat setuju, 16 peserta didik $(30,30 \%)$ yang memberikan tanggapan setuju, dan 1 peserta didik yang memberikan tanggapan kurang setuju terhadap pernyataan nomor (1) Penggunaan e-learning dalam pembelajaran Bahasa Indonesia membuat peserta didik senang .

Sebanyak 20 peserta didik $(45,45 \%)$ yang memberikan tanggapan sangat setuju, 24 peserta didik (54,54\%) yang memberikan tanggapan setuju terhadap penyataan nomor (2) Penggunaan $e$ learning dalam pembelajaran Bahasa Indonesia memungkinkan peserta didik untuk belajar sesuai dengan kecepatan belajarnya sendiri berdasarkan minat dan kebutuhan belajar peserta didik.

Sebanyak 36 peserta didik $(81,81 \%)$ yang memberikan tanggapan sangat setuju, 8 peserta didik $(18,18 \%)$ yang memberikan tangapan setuju terhadap pernyataan nomor (3) Penggunaan e-learning dalam pembelajaran Bahasa Indonesia memungkinkan peserta didik untuk belajar secara mandiri.

Sebanyak 16 peserta didik (36,36\%) yang memberikan tanggapan sangat setuju, 28 peserta didik (63,63\%) yang memberikan tanggapan setuju terhadap pernyataan nomor (4) E-learning dalam pembelajaran Bahasa Indonesia dapat berfungsi sebagai suplement, yaitu tambahan dalam pemebelajaran tatap muka untuk memperkaya pengalam belajar

Sebanyak 18 peserta didik (40,90\%) yang memberikan tanggapan sangat setuju, 25 peserta didik $(56,81 \%)$ yang memberikan tanggapan setuju, dan $1(2,27$ \%) peserta didik memberikan tanggapan kurang setuju terhadap peryataan nomor (5) E-learning dalam pembelajaran Bahasa Indonesia dapat berfungsi sebagai complement, yaitu untuk melengkapi pembelajaran tatap muka seperti penggunaan video online untuk mempermudah peserta didik memahami materi pelajaran.

Sebanyak 13 peserta didik $(29,54 \%)$ yang memberikan tanggapan sangat setuju, 25 peserta didik $(56,81 \%)$ memberikan tanggapan setuju, 5 peserta didik ( 11,36 \%) memberikan tanggapan kurang setuju, dan 1 peserta didik(2,27\%) memberikan tanggapan tidak setuju terhadap peryataan nomor (6) E-learning dalam pembelajaran Bahasa Indonesia dapat berfungsi sebagai replacement, yaitu untuk mengganti pembelajaran tatap muka.

Sebanyak 27 peserta didik $(61,36 \%)$ yang memberikan tanggapan sangat setuju dan 17 peserta didik $(38,63 \%)$ memberikan tanggapan setuju, terhadap peryataan nomor (7) E-learning dalam pembelajaran bahasa Indonesia dapat menjadi sumber ilmu atau informasi bagi peserta didik.

Selain data setiap butir peryataan dia atas, di bawah ini akan disajikan hasil respons peserta didik terhadap penggunaan e-learning dalam pembelajaran bahasa Indonesia di SMA Negeri Bali Mandara. Angket tersebut berisikan tujuh pernyataan. Adapun respons peserta didik penggunaaan elearning dalam pembelajaran bahasa Indonesia adalah sebagai berikut. dapat dijelaskan bahwa dari 44 peserta didik yang mengisi angket, terdapat 21 peserta didik $(47,72 \%)$ yang memberikan respons sangat setuju. Sisanya, yaitu 23 peserta didik $(52,27 \%)$ yang memberikan respons setuju. Oleh karena itu, dari 44 peserta didik tersebut tidak ada yang memberikan respons ragu-ragu, kurang setuju, dan tidak setuju. Berdasarkan kriteria tersebut, dapat 
ditarik simpulan bahwa rata-rata respons peserta didik terhadap penggunaan $e$ learning dalam pembelajaran bahasa Indonesia yaitu sangat positif $(31,45)$.

\section{Pembahasan}

Berdasarkan temuan yang telah dipaparkan pada bagian hasil penelitian, ada tiga temuan utama yang akan dibahas. Yang pertama adalah isi program e-learning memadai dan memiliki tiga daya dukung. Sebagaimana diketahui, program e-learning di SMA Bali Mandara menggunakan dua jenis kelas maya yakni quipper dan schoology. Isi e-learning pada quipper sudah berupa konten yang memiliki fungsinya masing-masing. Konten tersebut meliputi kode kelas, materi bahasa Indonesia, tugas online, dan hasil asessment. Sementara pada schoology isi e-learning meliputi akses kelas maya dengan kode kelas, materi bahasa Indonesia, materi tambahan, dan memfasilitasi evaluasi online. Hal tersebut harus ada pada isi e-learning, sehingga isi e-learning menjadi lebih lengkap. Hal tersebut sejalan dengan Effendi dan zhuang (2005:72) menyatakan ada beberapa perencanaan dalam e-learning, yaitu pada poin ke tiga menyatakan elarning dibagi menjadi dua bagian yaitu learning management sistem, dan learning management conten atau materi pelajaran. Pada pemebelajaran bahasa Indonesia tentu materi yang tersedia adalah materi bahasa Indonesia, sehingga sistem tersebut akan membantu dalam pembelajaran bahasa Indonesia.

Sementara materi tambahan dapat guru berikan kepada peserta didik sesuai dengan kebutuhan belajarnya. Guru dapat menyusun kembali materi dengan menambahkan materi yang tepat. Hal tersebut sejalan dengan pendapat Effendi dan zhuang (2005:72) menyatakan ada beberapa perencanaan dalam e-learning, yaitu pada poin ke- empat LCMS adalah sistem yang berfungsi menyusun materi atau conten. Seorang pengembang akan menciptakan storybord, menggabungkan, dan mengubah materi. Selain itu apabila peserta didik sudah selesai mempelajari tugas tersebut akan ada tugas online yang harus dikerjakan sebagai evaluasi. Dengan demikian telah diketahui bahwa isi $e$ learning dalam pembelajaran bahasa Indonesia di SMA Negeri Bali mandara sudah baik.

Berdasarkan temuan yang didapat, daya dukung e-learning terhadap pembelajaran bahasa Indonesia sangat tinggi. E-learning yang digunakan secara tepat dapat memberikan daya dukung yang tinggi. Daya dukung e-learning dalam pembelajaran bahasa Indonesia di SMA Negeri Bali Mandara meliputi, mempermudah guru dalam mengajar. Penggunaan e-learning dalam pembelajaran bahasa Indonesia telah memberikan daya dukung yang tinggi pada guru dalam mengajarkan materi bahasa Indonesia. Selain itu penggunaan $e$ learning juga menyediakan materi bahasa Indonesia. Materi yang tersedia sekiranya sering dilupakan oleh peserta didik, sehingga dengan e-learning materi akan tetap tersimpan dan bisa dipelajari kapanpun. Daya dukung e-learning juga terbukti dari adanya materi tambahan. Materi yang kurang pada kelas tatap muka akan diatasi dengan e-learning. Guru dan peserta didik dapat mengakses materi untuk memahami materi dengan maksimal. Hal ini sejalan dengan yang disampaikan Efffendi dan Zhuang (2005:22) pada poin pertama menyampaikan kegunaan penyusunan strategi untuk e-learning adalah memperjelas tujuan pelatihan atau pendidikan yang ingin dicapai. Artinya pada pendidikan di Indonesia memiliki tujuan pendidikan yang sangat beragam. Tujuan pelatihan atau pendidikan berbeda masingmasing organisasi ataupun departemen. Dengan tujuan tersebut pelatihan ataupun pendidikan harus sejalan dengan tujuan organisasi atau sekolah.Sebagai contoh peserta didik diharapkan lebih kreatif dan mandiri sehingga peserta didik perlu diberikan pelatihan menggunakan teknologi dalam pembelajaran, khususnya pembelajaran bahasa Indonesia.

Yang kedua adalah penggunaan $e$ learning dalam pembelajaran bahasa Indonesia di SMA Negeri bali Mandara terlaksana dengan baik. SMA Negeri Bali 
Mandara menerapkan e-learning dalam bentuk blended learning. Penggunaan $e-$ learning di SMA Negeri Bali Mandara tetap merupakan implementasi dari perencanaan yang dibuat oleh guru.

Secara teori menurut Effendi dan Zhuang ( 2005:7) penggunaan e-learning dapat dibedakan menjadi synchronous training yaitu pelatihan yang terjadi pada waktu saat yang bersamaan yakti ketika guru mengajar dan peserta didik belajar, asynchronous training yaitu pelatihan yang dilakukan pada waktu yang berbeda. Penggunaan e-learning di SMA Negeri Bali Mandara pada pembelajaran bahasa Indonesia sudah dilakukan dalam bentuk blended learning.

Pada pelaksanaan blended learning di SMA Negeri Bali Mandara pada pembelajaran bahasa Indonesia, dapat dilihat pada tiga tahap yakni pendahuluan, inti dan penutup. Penggunaan blended learning di SMA Negeri Bali Mandara pada pembelajaran bahasa Indonesia sudah dilakukan dengan baik, hal ini terbukti dari pembelajaran tatap muka maupun pembelajaran secara online sudah dilakukan secara berimbang. Hal ini, terbukti dari blended learning yang dilaksankan di SMA Negeri Bali Mandara dengan dengan tiga kegiatan yakni pendahuluan, inti dan penutup. Pada bagian pendahuluan guru mengarahkan peserta didik untuk masuk ke kelas maya dengan kode yang sudah disediakan Peserta didik masuk ke kelas maya dengan kode yang telah diberikan guru. Masuk ke dalam kelas maya sesuai dengan kode yang telah diberikan guru membuat peserta didik dapat, menggunakan kelas maya. Peserta didik mempelajari materi yang tersedia di kelas maya di asrama. Setelah peserta didik masuk ke kelas maya peserta didik dapat mengakses materi yang sudah ada pada kelas maya. Materi tersebut sudah disesuaikan dengan silabus. Peserta didik dapat mempelajari materi di asrama sebelum materi itu dibahas kembali di kelas tatap muka.

Pada bagian inti pembelajaran dilakukan sebagai mana mestinya pada kelas tatap muka, artinya pembelajaran yang disesuaikan langkah pembelajaran pada RPP yang sudah dibuat guru. Pada kegiatan inti, guru mereview pemahaman peserta didik terhadap materi yang sudah diberikan guru pada kelas maya. Penggunaan blended learning dengan tujuan agar hasil pembelajaran lebih maksimal, peserta didik yang sudah mempelajari materi pelajaran bahasa Indonesia dengan kelas maya diharapkan sudah memiliki pemahaman terhadap materi telaah buku nonfiksi yang diberikan guru. Pada pertemuan tatap muka, guru membahas materi untuk mengetahui pemahaman peserta didik, dengan memberikan pertanyaan-pertanyaan. Hal tersebut senada dengan Prayitno (2015) menambahkan pendekatan yang dilakukan, dapat memanfaatkan berbagai macam media dan teknologi. Dengan istilah lain blended learning adalah pembelajaran yang mengkombinasikan antara tatap muka (pembelajaran secara konvensional, di mana antara peserta didik dan pendidik saling berinteraksi secara langsung, masing-masing dapat bertukar informasi mengenai bahan-bahan pengajaran), belajar mandiri (belajar dengan berbagai modul yang telah disediakan) serta belajar mandiri secara online. .

Pada pelaksanaan blended learning dalam pembelajaran bahasa Indonesia di SMA Negeri Bali Mandara guru sudah membahas materi, pembelajaran blended learning sudah dilakukan. Peserta didik dapat belajar di asrama ketika tidak berlangsung pembelajaran tatap muka. pembelajaran blended learning yang sudah terprogram dengan baik, akan memudahkan peserta didik dalam memahami materi. Hal tersebut sejalan dengan pendapat Prayitno (2015) yaitu pada keuntungan blended learning pada poin ketiga Meningkatkan aksesbilitas. Dengan adanya blended Learning, maka peserta belajar semakin mudah dalam mengakses materi pembelajaran.

Temuan penelitian penggunaan $e-$ learning dalam pembelajaran bahasa Indonesia sejalan dengan penelitian berjudul "Pengaruh Penggunaan E-learning Berbasis Edmodo Terhadap Prestasi 
Belajar Matematika Peserta Didik kelas X Paket Keahlian Teknik Gambar Bangunan SMK Negeri 3 Singaraja" yang dilakukan oleh Gusti Ngurah Yogi Maha Putra, pada tahun 2016 yang sama-sama tergolong meneliti penggunaan e-learning dalam pembelajaran.

Penggunaan e-learning dalam pembelajaran bahasa Indonesia di SMA Negeri Bali Mandara sudah berjalan dengan sangat baik. Pembelajaran dalam bentuk blended learning, yang dapat dilihat dari tiga tahap pelaksanaannya, yaitu pendahuluan, kegiatan inti dan penutup.

Yang ketiga adalah peserta didik memberikan respons positif terhadap penggunaan e-learning dalam pembelajaran bahasa Indonesia. Hal tersebut dapat dilihat dari rata-rata respons peserta didik. Berdasarkan hasil penelitian dengan angket yang sudah disebar kepada 44 peserta didik yakni dijadikan sampel, ada $21(47,72 \%)$ orang menyatakan sangat positif, dan $23(52,27 \%)$ orang menyatakan positif. Dari data tersebut, diperolah simpulan bahwa secara keseluruhan respon peserta didikadalah sangat positif $(31,5)$. Respon sangat positif yang diberikan peserta didik memiliki arti bahwa peserta didik telah menyetujui dan menerima penggunaan e-learning dalam pembelajaran bahasa Indonesia. Hal tersebut sejalan dengan pendapat Harvey dan Smith (dalam Ahmadi, 1992:164) bahwa respons positif adalah sebuah respons, tindakan, atau sikap yang menunjukkan atau memperlihatkan, menerima, mengakui, menyetujui, serta melaksanakan norma-norma yang berlaku dimana individu itu berada.

Berdasarkan hasil angket yang telah diberikan kepada peserta didik kelas XI IPA I dan XI IPA II, dapat disimpulkan bahwa peserta didik merespons sangat positif penggunaan e-learning dalam pembelajaran bahasa Indonesia di SMA Negeri Bali Mandara.

Respon sangat positif terhadap penggunaan e-learning dalam pembelajaran bahasa Indonesia di SMA Negeri Bali Mandara, memiliki kesamaan dengan penelitian yang berjudul "Efektivitas
Media Pembelajaran E-learning Berbasis Quipper School terhadap pemahaman Konsep Matematika Peserta Didik Kelas X di SMA Laboratorium Undiksha" dilakukan olehl Gusti Ngurah Yatra Pratistha, tahun 2016 yang sama-sama tergolong positif.

\section{SIMPULAN DAN SARAN}

Ada empat simpulan yang dapat penulis ambil berdasarkan rumusan masalah, hasil penelitian,dan pembahasan. Simpulan tersebut adalah sebagai berikut.

1. Isi e-learning dalam pembelajaran bahasa Indonesia di SMA Negeri Bali mandara, yaitu menggunakan quipper, dan sechoology dimana isinya berupa konten yang sudah memiliki fungsinya masing- masing, yaitu (a) Kode kelas, (b) materi, (c) tugas online, (c) evaluasi. Sedangkan daya dukung e-learning dalam pembelajaran bahasa Indonesia di SMA Negeri Bali Mandara dapat dibagi menjadi tiga, yaitu (a) mempermudah guru dalam mengajar, (b) mendukung materi dalam silabus, (c) memfasilitasi evaluasi online.

2. Penerapan e-learning dalam pembelajaran bahasa Indonesia di SMA Negeri Bali Mandara, yaitu dalam bentuk blended learning. Pada pelaksanaannya, dapat dilihat pada setiap langkah pelaksanaan, yaitu pendahuluan, kegiatan inti dan penutup.

3. Respons peserta didik terhadap penggunaan e-learning dalam pembelajaran bahasa Indonesia di SMA Negeri Bali Mandara, yaitu sangat positif $(31,5)$.

Berdasarkan paparan mengenai hasil penelitian, dan simpulan adapun saran-saran yang dapat disampaikan peneliti adalah sebagai berikut.

1. Bagi Guru Bahasa Indonesia

Secara umum penggunaan e-learning dalam pembelajaran bahasa Indonesia di SMA Negeri Bali Mandara sudah sangat baik. Untuk kedepannya, sebaiknya guru tetap mempertahankan hal tersebut agar dapat lebih membantu guru dalam mengajarkan materi maupun peserta didik dalam belajar. 
2. Bagi Guru bahasa Indonesia lain.

Bagi guru bahasa Indonesia lainnya, yang belum menggunakan e-learning dalam pembelajaran bahasa Indonesia, penelitian ini diharapkan dapat dijadikan pedoman dalam penggunaan e-learning dalam pembelajaran bahasa Indonesia.

3. Bagi Peserta didik

Bagi peserta didik, penggunaan $e-$ learning dalam pembelajaran bahasa Indonesia, peneliti harapkan untuk dipertahankan dan ditingkatkan, agar keberhasilan dalam mencapai tujuan pembelajaran dapat terlaksana, dan peserta didik mampu menguasai materi dengan baik sesuai dengan materi yang ada pada e-learning maupun yang diberikan guru pada kelas tatap muka.

4. Bagi Sekolah

Pada daya dukung e-learning di SMA Negeri Bali Mandara sudah baik, kedepannya penulis mengahrapkan sekolah terus memanfaatkan e-learning, sehingga penggunaan e-learning tetap berjalan dengan lancar.

5. Bagi Peneliti Lain

Penelitian ini diharapkan dapat dijadikan acuan untuk meneliti masalah yang sejenis. Peneliti mengharapkan agar peneliti lain melakukan penelitian lanjutan terhadap penggunaan $e$ learning dalam pembelajaran bahasa Indonesia maupun mata pelajaran lain , sehingga didapatkan hasil yang lebih maksimal.

\section{DAFTAR PUSTAKA}

Ahmadi, Abu. 1992. Psikologi Umum. Jakarta: Rineka Cipta.

Daryanto. 2010. Media Pembelajaran. Yogyakarta: Gava Media.

Effendi, Empy dan Hartono Zhuang. 2005. E- learning Konsep dan Aplikasi.Yogyakarta: C.V. Andi Offset.

Ferry Apriana, Kadek 2015. Pengembangan Portal e-learning berbasis Schoology Pada Mata pelajaran IPS Kelas VIII di SMPN 1 Banjarangkan. Skripsi (tidak diterbitkan). Universitas Pendidikan Ganesha.
Kementrian Pendidikan dan Kebudayaan. 2015. Buku Guru Bahasa Indonesia SMA/MA/SMK/MAK Kelas $X$ Edisi Revisi 2014. Jakarta: Kementrian Pendidikan dan Kebudayaan.

Permendikbud Republik Indonesia Nomor 65 Tahun 2013 Tentang Standar Proses Pendidikan Dasar dan Menengah: Jakarta: Tidak diterbitkan.

Pratistha, Gusti Ngurah yatra. 2016. Efektivitas media pembelajaran elearning berbasis quipper school terhadap pemahaman konsep matematika peserta didik kelas $x$ di SMA laboratorium Undiksha. Skripsi (Tidak Diterbitkan). Jurusan Pendidikan Matematika, Fakultas Matematiak Dan IImu

Pengetahuan Alam. Universitas Pendidikan Ganesha.

Prayitno, Wendhie. 2015. Penerapan Blended Learning dalam Pengembangan Pendidikan dan Pelatihan (Diklat) bagi Pendidik dan Tenaga Kependidikan (PTK). (http://lpmpjogia.org/wpcontent/uploads/2015/08/Artikelbr 10juli-Penerapan-BlendedLearning-dalam-PengembanganDiklat-PTK Wendhie.pdf) diakses pada 18 Juli 2018.

Putra Rezema, Sitiatava. 2013. Desain Belajar Mengajar Kreatif Berbasis Sains. Jogjakarta: DIVA Press.

Maha Putra, Gusti Ngurah Yogi. 2016. Pengaruh Penggunaan ELearning Berbasis Edmodo terhadap Prestasi BelajarMatematika peserta didik Kelas X Paket Keahlian Teknik Gambar Bangunan SMK Negeri 3 Singaraja. Skripsi (TidakDiterbitkan). Jurusan PendidikanMatematika, Fakultas Matematiak danllmu Pengetahuan Alam. UniversitasPendidikan Ganesha.

Shofiyah, Siti. 2016. Pengaruh Penggunaan Android dan E-learning terhadapHasil Belajar Mata 
Pelajaran IPSPeserta didik Kelas VIII SMPN 3 Kepanjen Malang. Skripsi(Tidak diterbitkan). JurusanPendidikan Ilmu Pengetahuan Sosial, Fakultas IImu Tarbiyahdan

Keguruan, Universitas Islam Negeri Maulana Malik Ibrahim Malang.

Sugiyono. $2007 . \quad$ Metode PenelitianPendidikan: Pendekatan Kuantitatif, Kualitatif dan $R \& D$. Bandung: Alfabeta.

Undang-Undang Republik Indonesia Nomor 20 Tahun 2003 tentang Sistem Pendidikan Nasional. Jakarta: tidak diterbitkan.

Wahyuningsih, Dian dan Rakhmat Makmur.2017. E-learning Teori dan Aplikasi.Bandung: Informatika Bandung.

Dengan ini menyatakan bahwa artikel di bawah ini:

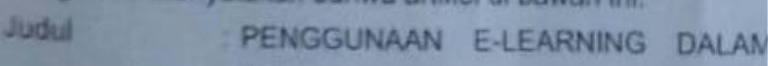

INDONESIA DI SMA NEGERI BALI MANI

I PUTU DARMIKA

Pembimbing I : DRS, GEDE GUNATAMA, M.HUM.

Pembimbing II PROF. DR. IMADE SUTAMA. M.PD.

Program Studi : PENDIDIKAN BAHASA DAN SASTRA IN

Slap untuk dipublikasikan pada Pendidikan Bahasa dan Sas

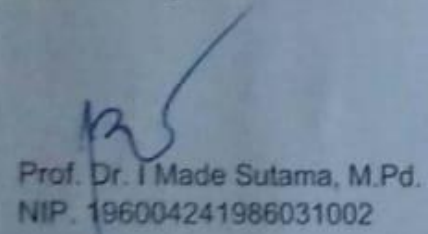


